УДК $81 ' 374$

DOI: $10.17223 / 22274200 / 9 / 6$

\title{
О.П. Фесенко
}

\section{КОМПЬЮТЕРНЫЙ СЛОВАРЬ ФРАЗЕОЛОГИЗМОВ ДРУЖЕСКИХ ПИСЕМ ПУШКИНСКОЙ ПОРЫ: ПРОЕКТ ДИСКУРСИВНОГО ДИНАМИЧЕСКОГО СЛОВАРЯ}

\begin{abstract}
В статье рассматривается возможность создания компьютерного словаря фразеологизмов дружеских писем первой трети XIX в. Приводится его структура, описывается содержание словарной статьи: значения фразеологической единицы, стилистическая окраска (в сопоставлении с данными словарей XVIIXXI вв.), окказиональнье варианты, исчерпьвающий перечень примеров употребления и т.п. Анализируются возможности словаря отражать динамику фразеологического состава языка и дискурсивные свойства фразеологизмов.

Ключевые слова: компьютерная лексикография, фразеологический словарь, дискурсивный словарь, динамический словарь.
\end{abstract}

$\int^{2}$ ексикография - активно развивающаяся отрасль современной лингвистики. Сегодня в арсенале лексикографов огромное разнообразие словарей самых разных типов и жанров. С каждым годом их становится все больше. В наши дни лексикография переживает свой расцвет, начавшийся в середине XX столетия. Если анализировать особенности развития лексикографической практики, то можно отметить, что среди множества направлений выделяется разработка компьютерных словарей и словарей новых типов, в которых авторы и составители пытаются отразить антропоцентричность речи и динамику языковой системы.

Словарная работа на протяжении всего своего существования движется «от значения к смыслу». Такое направление развития связано, прежде всего, с тем, что, как верно отмечал А. Рей, объектом описания в толковом словаре «могут выступать две разные реальности, что влечет за собой два возможных типа описаний» [1. С. 264]. Речь идет о словарях системы (или ее элементов: слов, фразеологизмов) и словарях употреблений. Это различие, по мнению ученого, для одноязычной лексикографии носит фундаментальный характер. «Толковый словарь либо может строиться как описание лексического компонента языковой системы, либо может быть нацелен на более широкое изучение, охватывающее действие этой системы в различных сферах ее употребления» [1. С. 265]. Объединить оба на- 
правления в развитии лексикографии может динамический дискурсивный компьютерный словарь. Сложной задачей для исследователя становится необходимость продемонстрировать не просто динамичность конкретного языкового периода или особенности языка конкретной языковой личности. В словаре нового типа сделать это надо одновременно (в рамках одного лексикографического издания) с учётом двух важнейших составляющих:

1) тех дискурсивных особенностей, которые позволяют выявить языковую динамику;

2) необходимости показать особенности конкретной языковой личности, продукт речевой деятельности которой становится предметом лексикографирования.

Таким словарем может стать компьютерный словарь фразеологизмов дружеских писем пушкинской поры, отражающий одновременно дискурсивные свойства фразеологических единии и динамические особенности фразеологического состава языка. В этой связи задача нашей статьи - показать возможности такого словаря, позволяющего отражать не только черты языковой системы (в нашем случае - фразеологии как ее части), но и различного рода ее динамические характеристики, проявляющиеся не в языке, а в речи.

В словарь вошли тексты, временные рамки которых - 18121858 гг. На первый взгляд может показаться, что обозначенные широкие границы лишь частично связаны с эпохой А.С. Пушкина, однако это не так. В рассмотренном нами материале содержатся письма только тех авторов, которые были современниками А.С. Пушкина, вели с ним переписку, являлись носителями общей языковой традиции. К сожалению, практически все они рано ушли из жизни. Только письма Н.М. Языкова и И.И. Пущина распространяются за пределы 30-х гг. XIX в. Таких писем немного (порядка 15 \% от общей массы исследованных текстов). Но их анализ позволяет убедиться, что специфика функционирования фразеологии в пределах эпистолярного наследия одного автора не меняется с течением времени. Языковые традиции пушкинского периода отражались в эпистолярном наследии его современников еще достаточно долгое время, пережив очередной этап в развитии русского языка, связанный с именами Н.В. Гоголя и И.С. Тургенева.

Поясним некоторые особенности определения жанра словаря.

Рассмотрим, что такое динамический словарь. Сам термин «динамический словарь» появился в конце XX столетия и обозначает 
способность словаря описывать «динамику слова в языке в определенный исторический период» [2. С. 389]. Происходящие в языке изменения затрагивают различные его уровни и вызваны, соответственно, разными причинами. Язык меняется с течением времени. Попытки создания динамических словарей, отражающих изменения в системе языка конкретной эпохи, известны как в зарубежной, так и в отечественной лексикографии. За рубежом это прежде всего «Словарь изменения значений», вышедший в Лондоне в 1986 г. [3], в отечественной лексикографической практике - словари языковых изменений конца XX столетия [4-8].

В названных нами лексикографических изданиях возможности проследить динамику языковой, в том числе фразеологической, системы очень ограничены. Сами авторы таких работ отмечают, что демонстрируют в словарных статьях не собственно процесс изменений, а уже их результат. Иными словами, в словарь включаются «именно те лексические разряды и группы, которые наиболее активно функционируют и формируют языковое сознание современников» [8. С. 6].

В этом отношении словарь остается всё-таки тем средством, которое содержит в себе сведения только об одном периоде развития языка. В связи с этим возникает необходимость создания динамических словарей - словарей переходных эпох (пушкинской поры, рубежа XX-XXI вв.), содержащих в себе сведения об изменении произношения, значения, сочетаемости, частоты употребления или каких-либо других параметров слов / фразеологизмов / словосочетаний и пр. на протяжении заявленного периода, но не автономно, а в сопоставлении с предыдущим и последующим этапами развития языка. Открывая такой словарь, читатель видит, что' происходило с конкретной языковой единицей в описываемый период.

Динамический словарь в нашем понимании должен дать возможность проанализировать особенности функционирования языковой единицы не за конкретный период, а на протяжении гораздо более длительного времени, включающего в себя переломные, ключевые этапы, коренным образом повлиявшие на становление и развитие языка. В первой трети XIX в. происходит формирование современного русского литературного языка (в широком понимании термина), поэтому в словаре можно отразить все те особенности, которые характерны как для предыдущей языковой эпохи, так и для последующих. Такую возможность дает, прежде всего, электронная 
версия словаря. В этом смысле словарь действительно будет являться динамическим.

Другие изменения, которые печатному словарю отразить уже сложнее, связаны с конкретными ситуациями коммуникации, с дискурсом. Именно поэтому сегодня в лексикографической практике идет активная работа по созданию таких словарей, которые отражали бы особенности использования различных языковых ресурсов с учётом конкретных речевых жанров, речевых ситуаций или свойств языковой личности, процесс и результат речевой коммуникации которой тоже рассматривается как дискурс. В этом направлении работа ведется достаточно давно. Хорошо известны словари языка писателей и поэтов (А.С. Пушкина [9], Ф.М. Достоевского [10], К.Г. Паустовского [11], В.М. Шукшина [12], С. Есенина [13], М. Шолохова [14], А.Н. Островского [15], А.А. Дельвига [16], И.А. Бунина [17], А.С. Грибоедова [18] и т.д.), словари языка ученых и общественных деятелей (М.В. Ломоносова [19], В.И. Ленина [20], А. Лебедя [21]), словари языка отдельных языковых личностей - носителей диалекта (Агафьи Лыковой [22] и др.). Идет работа по составлению словарей отдельных дискурсов (языка деловых документов [23], языка средств массовой информации [24], языка города [25] и т.д.). Хотя абсолютное большинство словарей имеет традиционную структуру словарной статьи, включающую ограниченное количество примеров функционирования языковых единиц, тем не менее лексикографы ведут активный поиск той лексикографической формы, которая позволила бы отразить особенности функционирования единиц языка в дискурсе. Поясним, в чем же состоит особенность словаря дискурса (или дискурсивного словаря).

Под дискурсом мы понимаем речь, вписанную в коммуникативную ситуацию и «связанную не только с актом создания определенного текста, но и со значительным количеством экстралингвистических факторов - знаний о мире, намерений, установок и конкретных целей говорящего, который является создателем дискурсивного текста» [26. С. 6].

Попытки создания дискурсивных словарей в современной лексикографии связаны с необходимостью отразить особенности функционирования языковых единиц в живом общении (в рамках какойлибо сферы коммуникации или как результата речевой деятельности конкретного носителя языка). К числу таких работ можно отнести, к примеру, «Материалы к словарю дискурсивных единиц» [27]. Дис- 
курсивными можно считать словари идиолектов, так как они представляют собой «результат речевой деятельности конкретного носителя языка» и отражают «дискурсивные практики конкретного индивида, реальной языковой личности» [28. С. 8, 11].

Кроме того, в последнее время лексикографы создают словари, которые отражают особенности функционирования языковых единиц в различных коммуникативных сферах (СМИ, городская среда и т.д.). Кроме того, следует сказать и о попытке составления когнитивно-дискурсивного словаря, который позволяет отследить не только значения отдельных языковых единиц, сколько специфику формирования дополнительных смыслов в структуре значения [29].

Дружеские письма, которые становятся источником языкового материала для нашего словаря, позволяют описать не только язык, но и дискурс. При определении дружеского эпистолярия как дискурса важным является тот факт, что последний создается в процессе взаимодействия коммуникантов и отражает на языковом уровне контакты и межличностные отношения между автором и адресатом. По нашему мнению, выявление дискурсивной природы эпистолярия дает возможность рассматривать массив дружеских писем первой трети XIX в. как целостное образование, поскольку абсолютное большинство текстов русскоязычной переписки обладает общими дискурсивными свойствами, реализующимися на всех уровнях организации писем. Именно поэтому дружеские письма становятся максимально информативным источником для дискурсивного словаря, демонстрирующего через анализ контекстов все те дополнительные смыслы, которые возникают у языковых единиц в процессе их функционирования. Компьютерная форма словаря в этом аспекте дает возможность проводить анализ контекстов как отдельных участников дискурсивного общения и сопоставлять примеры функционирования фразеологизмов в текстах разных авторов и отслеживать причины возникновения дополнительных значений у языковых единиц.

Скажем несколько слов по поводу того, почему именно фразеологизмы стали предметом описания в словаре. Фразеологизм - это «раздельнооформленная <..> единица языка, которая соотносится по общим и частным семантическим и грамматическим свойствам со словом определенной части речи, и являясь раздельнооформленной $<\ldots>$ единицей языка, выражает единое целостное понятие» [30 C. 4]. Это узкое понимание фразеологии, при котором в состав фра- 
зеологизмов включаются фразеологические единицы, квалифицирующиеся по теории В.В. Виноградова как единства и сращения. Фразеологические единицы достаточно консервативны по структуре и содержанию. Изменения в форме и значении фразеологизма - процесс долгий, не одномоментный. Проследить его в полном объеме удается только тогда, когда материалом для исследования становятся тексты, функционирующие в ключевые для развития языка периоды (как в нашем случае - первая треть XIX в.). При этом эпистолярий максимально приближен к живому общению (хотя, безусловно, не совпадает с ним полностью), что позволяет увидеть изменения фразеологии именно в рамках дискурса. Дискурсивные свойства писем реализуются на всех уровнях организации текста. Фразеология не является в этом аспекте исключением. Фразеология дружеских писем первой трети XIX в. -ярчайшее средство реализации дискурсивных свойств дружеской переписки: антропоцентричности, полифункциональности, креативности и диссимметрии (см. об этом подробнее [31. С. 42; 32. С. 295; 33. С. 9; 34. С. 47].

Источником составления словаря послужила авторская картотека, включающая в себя 1026 фразеологических единиц (далее - ФЕ) (5490 употреблений фразеологизмов), функционирующих в дружеских письмах пушкинского периода: эпистолярное наследие А.С. Пушкина (647 текстов), А.С. Грибоедова (73 текста), Н.М. Языкова (146 текстов), А.А. Дельвига (95 текстов), Е.А. Боратынского (68 текстов), И.И. Пущина (612 текстов), А.И. Одоевского (48 текстов), декабристов (24 текста). Временные рамки исследованных текстов 1812-1858 гг. На первый взгляд может показаться, что обозначенные широкие границы лишь частично связаны с эпохой А.С. Пушкина, однако это не так. В рассмотренном нами материале содержатся письма только тех авторов, которые были современниками А.С. Пушкина, вели с ним переписку, являлись носителями общей языковой традиции. К сожалению, практически все они рано ушли из жизни. Только письма Н.М. Языкова и И.И. Пущина выходят за пределы 30х гг. XIX в. Таких писем немного (около $15 \%$ от общего количества исследованных текстов), но их анализ позволяет убедиться, что специфика функционирования фразеологии в пределах эпистолярного наследия одного автора не меняется с течением времени.

Итак, словарь, заявленный как динамический и дискурсивный, призван представить изменения, происходящие во фразеологическом фонде языка первой трети XIX в. с учетом тех особенностей 
функционирования фразеологизмов, которые проявляются в текстах писем как в дискурсе. В полном объеме эта возможность может быть реализована в формате электронного словаря.

По нашему мнению, словарная статья такого электронного лексикографического издания должна включать сведения, касающиеся особенностей структуры, семантики, стилистики фразеологизмов не только в описываемый период, но предшествующих и последующих эпох и разницы в их значениях и особенностях функционирования в текстах разных авторов. Сделать это необходимо еще и потому, что язык пушкинской эпохи «требует пояснений, поскольку за прошедшие столетия произошло много семантических изменений, поэтому современный читатель не всегда может извлечь именно тот смысл, который в него вкладывал автор» [35. С. 2].

В словарной статье такой материал может быть представлен следующим образом (рис. 1).

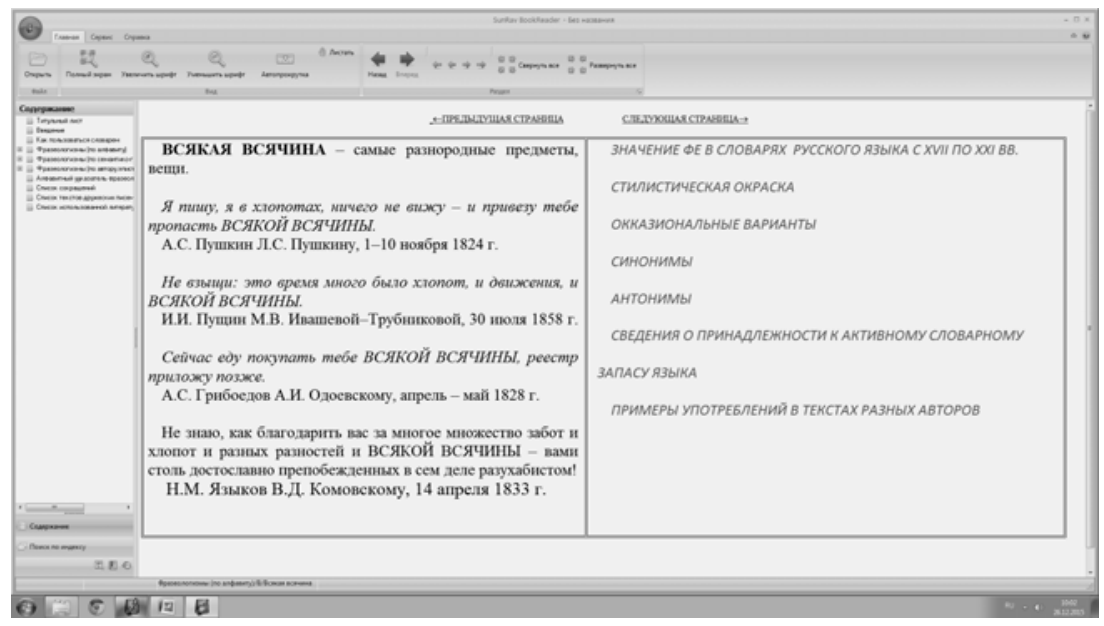

Рис. 1

Как видно из приведенного примера, словарь дает возможность в достаточном объеме получить сведения о фразеологической единице (как в динамическом, так и в дискурсивном аспектах). Динамический аспект представлен с помощью ссылок в правой части экрана (значения в словарях русского языка с XVII по XXI в., стилистиче- 
ская окраска ${ }^{14}$, сведения о принадлежности к активному словарному запасу языка с точки зрения современного русского языка и, если есть возможность сделать соответствующие выводы, то и языка пушкинской эпохи). Перечисленная информация выплывает на экране при подведении курсора к необходимой читателю строке (рис. 2).

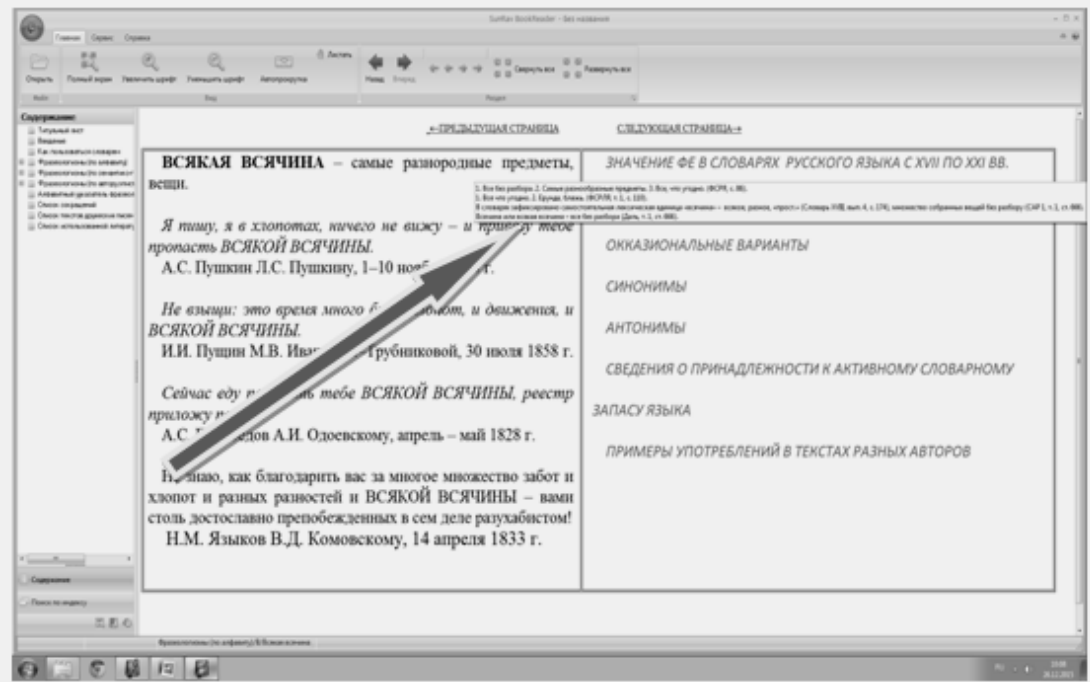

Рис. 2

Поскольку продемонстрировать особенности электронного словаря сложно, подробно представим информацию, появляющуюся в выплывающем окне «Значение ФЕ в словарях русского языка с XVII по XXI в.» (выплывающее окно с текстом распложено на слайде и отмечено стрелкой для более детального описания возможностей словаря в статье):

1. Все без разбора. 2. Самые разнообразные предметы. 3. Все, что угодно. (ФСРЯ, с. 86).

1. Все что угодно. 2. Ерунда, блажь. (ФСРЛЯ, т. 1, с. 110).

${ }^{14}$ Анализ фразеологического значения и стилистической окраски проведен с опорой на 28 лексикографических изданий. 
В словарях зафиксирована самостоятельная лексическая единица «всячина» - всякое, разное (Словарь XVIII, вып. 4, с. 174), множество собранных вещей без разбору (САР 1, т. 1, ст. 666).

Всячина или всякая всячина - все без разбора (Даль, т. 1, ст. 666).

Дискурсивный аспект фразеологизмов отражен в их окказиональных вариантах, в активности использования в пределах дружеского эпистолярия фразеологических синонимов и антонимов (если они функционируют в письмах и имеются в языке), в примерах употреблений ФЕ в текстах разных авторов. В левой части статьи приводится 3-4 примера употребления фразеологизма. В правой (при активации соответствующей ссылки) - все контексты функционирования ФЕ. Именно в этой последней части статьи представлены сведения:

1) о появлении дополнительных субъективных смыслов у фразеологизма. Например, ФЕ САХАР МЕДОВИЧ в письмах А.С. Грибоедова имеет не общеязыковое значение «льстивый, слащавый человек», а употреблено как парафраз по отношению к конкретному человеку, хорошо известному и автору и адресату своими личностными характеристиками (льстивостью) (Ферзь тоже разочарована на счет своего САХАРА МЕДОВИЧА. А.С. Грибоедов П.А. Катенину, январь 1825 г.);

2) об особенностях использования фразеологизмов разными авторами. Так, фразеологическая единица ВЫХОДИТЬ / ВЫЙТИ ИЗ КАРМАНА в современном русском языке не зафиксирована и может быть определена как окказиональная (встречается только в письмах И.И. Пущина). При этом в словарной статье видно, что данный фразеологизм имеет антоним НЕ ХОДИТЬ / ПОЙТИ В КАРМАН (в эпистолярии А.И. Одоевского). Хотя сведений пока недостаточно для окончательных выводов, тем не менее можно утверждать, что приведенная в словаре ФЕ известна участникам дискурса и используется ими.

В силу того, что словарь имеет электронный формат, представить в статье в полном объеме его возможности проблематично. Добавим, что навигация в словаре осуществляется двумя способами: 1) с помощью гиперссылок «СЛЕДУЮЩАЯ СТРАНИЦА», «ПРЕДЫДУЩАЯ СТРАНИЦА», «ВЕРНУТЬСЯ НА СТРАНИЦУ» с указанием ее названия и т.д.); 2) с помощью содержания, в котором подробнейшим образом расписаны все фразеологизмы (как в алфавитном 


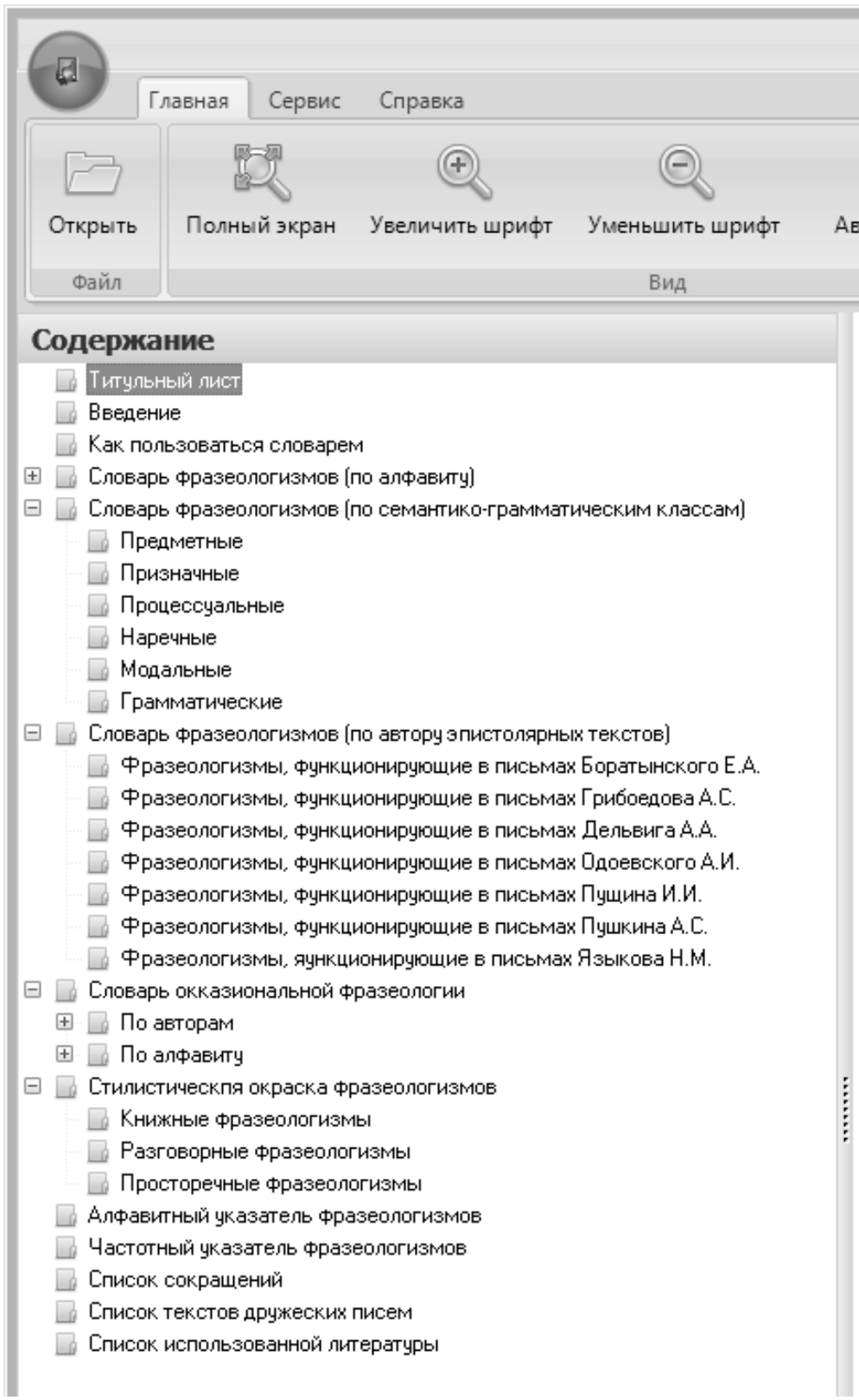

Рис. 3 
порядке, так и по семантико-грамматическим классам и по принадлежности к конкретному автору эпистолярия). В словаре имеется алфавитный указатель фразеологизмов, список сокращений и использованной литературы (словарных источников и научных изданий, на которые ссылается автор словаря при уточнении значений и происхождения некоторых фразеологизмов), подробная инструкция о том, как пользоваться словарем, и т.д. Представим структуру словаря наглядно (рис. 3).

Информацию подобного рода может с успехом представлять печатный вариант словаря. Однако у него есть некоторые недостатки, связанные с тем, что объем такого издания ограничен, поэтому провести полный анализ функционирования конкретных языковых единиц сложно. Обычно авторы ограничиваются 1-2 контекстами или, в лучшем случае, указывают число зафиксированных употреблений. Компьютерная модификация словаря в этом отношении более продуктивна и функциональна. Она открывает исследователю возможности изучать особенности употребления фразеологизмов конкретными авторами, позволяя выводить на экран все найденные контексты с конкретной анализируемой единицей. Кроме того, компьютерный словарь может демонстрировать контексты выборочно, по определенным важным для исследователя критериям, например только те, которые встречаются в письмах А.С. Пушкина или исключительно в эпистолярии И.И. Пущина, А. Дельвига и т.д. Печатный фразеологический словарь чаще всего описывает единицы, представляя их в алфавитном порядке. Такое расположение удобно для большинства пользователей, особенно если они не являются специалистами в области лингвистики. Однако «алфавитный словарь - это случайный лексический массив, поскольку в сознании и, следовательно, в языке слова упорядочены путем вхождения в некий понятийный ряд, лексико-семантическую или тематическую группу» [26. С. 29]. Поэтому для лингвистов алфавитный порядок не всегда информативен, а чаще вообще неинформативен. Компьютерный словарь может, учитывая потребности пользователя, представлять материал по другим параметрам (частота употребления, стилистическая окраска, категориальное значение фразеологических единиц (предметные, призначные, процессуальные фразеологизмы и т.д.), отдельно выводить на экран окказиональные варианты и т.д.). Эти возможности безграничны и открывают самые широкие перспективы для исследователей языка. 
Таким образом, компьютерный дискурсивный динамический словарь может стать максимально продуктивным источником для лингвистических исследований, осуществляемых в самых различных направлениях, давая возможность учёным максимально использовать потенциал того языкового материала, который становится предметом описания в словаре.

\section{Лuтература}

1. Рей А. Проблемы и антиномии лексикографии / А. Рей, С. Делесаль // Новое в зарубежной лингвистике. - Вып. 14: Проблемы и методы лексикографии. - М., 1983. - С. 260-299.

2. Жданов Е.A. Лексикографическая фиксация неологизмов в словарях разных типов // Вестн. Нижегород. ун-та им. Н.И. Лобачевского. - 2012. - № 3 (1). - С. $388-$ 392.

3. Room Adrian. Dictionary of changes in meaning. - London; New York : Routledge\& Kegan Paul, 1986. - 292 p.

4. Катлинская Л.П. Толковый словарь новых слов и значений русского языка : ок. 2000 слов: [слова, появившиеся в русском языке в конце XX - начале XXI века, толкование значений, грамматические формы, грамматические и стилистические пометы, словообразовательные гнезда, этимологическая справка у иноязычных слов, русские эквиваленты иноязычных слов, иллюстрации из художественной и публицистической литературы, теле- и радиопередач]. - М.: АСТ: Астрель , 2008. - 380 с.

5. Новые слова и значения: Словарь-справочник по материалам прессы и литературы 90-х годов XX века: в 2 т. / отв. ред. Т.Н. Буцева. - СПб.: Дмитрий Буланин, $2009-2014$.

6. Словарь новых слов русского языка (середина 50-х - середина 80-х годов) / Рос. акад наук, Ин-т лингв. исслед.; [Е.А. Левашов и др.]; под ред. Н.3. Котеловой. СПб. : Дмитрий Буланин, 1995. - 876 с.

7. Толковый словарь русского языка начала XXI века: Актуальная лексика: ок. 8500 слов и устойчивых словосочетаний / под ред. Г.Н. Скляревской. - М.: Эксмо, 2008. $-1136 \mathrm{c}$.

8. Толковый словарь современного русского языка : Языковые изменения конца XX столетия / Рос. акад. наук. Ин-т лингв. исслед.; под ред. Г.Н. Скляревской. - М.: Астрель : АСТ, 2001. - 894 с.

9. Словарь языка Пушкина: в 4 т. / Рос. акад. наук. Ин-т рус. яз. им. В.В. Виноградова; [сост.: С.И. Бернштейн и др.]. - 2-е изд., доп. - М. : Азбуковник : Ин-т рус. яз. им. В.В. Виноградова, 2000.

10. Словарь языка Достоевского: Лексический строй идиолекта: в 2 кн. / Рос. акад. наук. Ин-т рус. яз. им. В.В. Виноградова; [авт.-сост.: Е.Л. Гинзбург и др.]; гл. ред. Ю.Н. Караулов. - М. : Азбуковник, 2001-2002.

11. Словарь языка К.Г. Паустовского : в 8 т.- М. : Изд-во Моск. лит. музеяцентра К.Г. Паустовского, 1998.

12. Байрамова Т.Ф. Словарь языка рассказов В.М. Шукшина: в 3 вып. / Т.Ф. Байрамова, В.П. Никишаева. - Бийск : НИЦ БПГУ им. В.М. Шукшина, 2002.

13. Шипулина Г.И. Словарь языка Есенина : глагол. - Баку : Мутарджим, 2013. -462 c. 
14. Словарь языка Михаила Шолохова / [Диброва Е.И. и др.]. - М.: Словари. py, 2014. $-377 \mathrm{c}$.

15. Словарь языка А.Н. Островского : [в 4 т.] [сост.: А.А. Хуснутдинов, А.А. Хуснутдинова]. - Шуя : ШГПУ, 2012.

16. Васильев Н.Л. Словарь языка А.А. Дельвига / Н.Л. Васильев, Д.Н. Жаткин. - М.: Флинта : Наука, 2009. - 147 с.

17. Васильев А.И. Фразеологический словарь языка И.А. Бунина. - Елец : Елец. гос. ун-т им. И.А. Бунина, 2011. - 391 с.

18. Поляков А.Е. Словарь языка А.С. Грибоедова. - Т. 1. - М.: Языки славянской культуры, 2011. - 430 с.

19. Словарь языка М.В. Ломоносова : [материалы к словарю языка М.В. Ломоносова] : в 2 кн. - СПб.: Нестор-История, 2010.

20. Словарь языка В.И. Ленина: проект / отв. ред. Ф.П. Филин; АН СССР. Инт рус. яз. - М., 1974. $-66 \mathrm{c.}$

21. Самотик Л.Г. Словарь языка Александра Лебедя. - Красноярск : Амальгама, 2004. - $326 \mathrm{c}$.

22. Толстова Г.А. Словарь языка Агафьи Лыковой. - Красноярск: РИО ГОУ ВПО КГПУ им. В.П. Астафьева, 2004. - 558 с.

23. Вафин Б.Д. Россия и Восток : словарь языка документов по русскоиндийским отношениям XVII века : конкорданс, обратный словоформоуказатель, частотный словоформоуказатель / Б.Д. Вафин, К.Р. Галиуллин. - Казань : Казан. гос. ун-т, 2012. $-251 \mathrm{c}$.

24. Элмор Р.Т. Словарь языка средств массовой информации США. - М. : Рус. яз., 1992. $-668 \mathrm{c}$.

25. Шарипова O.A. Словарь языка города : (региональный аспект: г. Стерлитамак, Республика Башкортостан). - Стерлитамак: Стерлитамак. филиал. Башкир. гос. ун-та, 2012. - 165 с.

26. Рогалева О.С. Брачное объявление как речевой жанр рекламного дискурса (коммуникативно-прагматический и когнитивный аспекты): автореф. дис. ... канд. филол. наук. - Омск, 2005. - 22 с.

27. Богданова-Бегларян Н.В. Конструкция «скажем» в повседневной русской речи (материалы к словарю дискурсивных единиц) // Вестн. Калмыц. Ин-та гуманит. исследований РАН. - 2012. - № 2. - С. 153-157.

28. Иванияова E.B. Лексикографическое представление речи индивида: тип словаря и его реализация в словарной практике // Вопр. лексикографии. - 2013. № 2 (4). - C. 5 -18.

29. Убийко В.И. Когнитивно-дискурсивный словарь в коммуникативном аспекте / В.И. Убийко, А.Р. Батталова // Когнитивные исследования. - 2012. - № 11. С. $546-548$.

30. Чепасова А.М. Семантические и грамматические свойства фразеологизмов. - Челябинск: Изд-во ЧГПИ, 1983. - 92 с.

31. Гвазава В.И. Эпистолярное наследие элитного российского дворянства // Русский язык: исторические судьбы и современность: междунар. конгресс исследователей русского языка: труды и материалы, 13-16 марта 2001 / под общ. ред. М.Л. Ремневой, А.А. Поликарпова. - М., 2001. - С. 42.

32. Касавин И.Т. Миграция. Креативность: Проблемы неклассической теории познания. - СПб.: РХГИ, 1998. - 408 с.

33. Ковалева Н.А. Русское частное письмо XIX века: Коммуникация. Жанр. Речевая структура: автореф. дис. ... д-ра филол. наук. - М., 2002. - 48 с. 
34. Гак В.Г. Асимметрия // Языкознание: Большой энцикл. сл. / гл. ред. В.Н. Ярцева. - М., 1998. - С. 47.

35. Дронова Л.П. Лексикографические проблемы в свете антропологической лингвистики // Вопр. лексикографии. - 2012. - № 2. - С. 26-32.

\section{Список сокращений}

ФСРЯ - Фразеологический словарь русского языка / Л.А. Войнова, В.П. Жуков, А.И. Молотков, А.И. Федоров; под ред. А.И. Молоткова. - М.: Рус. яз., 1987. - 543 с.

ФСРЛЯ - Фразеологический словарь русского литературного языка: в 2 т. / сост. А.И. Федоров. - М.: Цитадель, 1991.

Словарь XVIII - Словарь русского языка XVIII века. - Вып. 1-14. - Л.: Наука, $1984-2004$.

САР 1 - Словарь Академии Российской 1789-1794: в 6 т. - М.: МГИ им. Е.Р. Дашковой, 2001-2006.

Даль - Даль В.И. Толковый словарь живого великорусского языка: в 4 т. - М.: Прогресс: Универс, 1994.

COMPUTER DICTIONARY OF PHRASEOLOGICAL UNITS OF FRIENDLY LETTERS OF PUSHKIN'S TIME: A PROJECT OF A DISCURSIVE DYNAMIC DICTIONARY

Voprosy leksikografii - Russian Journal of Lexicography. 2016. 1 (9). 82-98.

DOI: $10.17223 / 22274200 / 9 / 6$

Fesenko Olga P., Omsk Tank Engineering Institute (Omsk, Russian Federation). E-mail: Olga.Fesenko2015@yandex.ru

Keywords: computational lexicography, dictionary, discourse dictionary, dynamic dictionary.

Dictionary work throughout its existence moves from meaning to sense. Such a direction of development is due to the fact that the object of description in an explanatory dictionary can be two different realities: language and speech. A discursive dynamic dictionary of idioms can unite them.

The source of the compilation of the dictionary was the author's card index including 1026 idioms identified by the method of continuous sampling of texts of friendly letters of Pushkin's time.

The dictionary aims to present the changes taking place in the phraseological fund of the language of the first third of the nineteenth century as a system with the features of functioning of idioms that appear in the texts of letters as in a discourse. In full this can be implemented in the format of an electronic dictionary.

The dictionary gives an opportunity to obtain information about the idiom (both in dynamic and discursive aspects) in a sufficient volume. The dynamic aspect is represented through links (meanings in the dictionaries of the Russian language from the 17th to the 21 st century, stylistic colouring, details on belonging to the active vocabulary of the language from the point of view of modern Russian language and, if it is possible to draw appropriate conclusions, language of Pushkin's epoch). The listed information comes up on the screen when the cursor is on the line the reader needs.

The discursive aspect of idioms is reflected in their occasional variations in the usage activity of phraseological synonyms and antonyms within the friendly correspondence (if 
they operate in letters and in language), in the examples of the usage of idioms in texts of different authors.

The dictionary is navigated in two ways: 1) using hyperlinks; 2) using the content, which exhaustively presents all the idioms (in alphabetical order, as belonging to semanticgrammatical classes, as belonging to a particular author). The dictionary has an alphabetical list of idioms, a list of abbreviations and references (dictionary sources and scientific publications the author of the dictionary uses when specifying meanings and origins of certain idioms), detailed instructions on how to use the dictionary, etc.

The computer dictionary can, taking into account the user's needs, organise the material by other parameters (frequency, style, categorical meaning of idioms (subject, attribute, process idioms, etc.), separately display occasional options, etc.). The opportunities are endless and open up broad prospects for researchers of language.

The computer discursive dynamic dictionary may become the most productive source for linguistic studies carried out in various directions, allowing scholars to maximize the potential of the linguistic material which becomes the subject of description.

\section{References}

1. Ray, A. \& Delesal, S. (1983) Problemy i antinomii leksikografii [Problems and antinomy of lexicography]. In: Novoe v zarubezhnoy lingvistike [New in foreign linguistics]. Is. 14. Moscow: Progress. pp. $260-299$.

2. Zhdanova, E.A. (2012) Lexicographical fixation of neologisms in dictionaries of various types. Vestnik Nizhegorodskogo universiteta im. N.I. Lobachevskogo - Vestnik of Lobachevsky University of Nizhni Novgorod. 3 (1). pp. 388-392. (In Russian).

3. Room, A. (1986) Dictionary of changes in meaning. London; New York: Routledge \& Kegan Paul.

4. Katlinskaya, L.P. (2008) Tolkovyy slovar' novykh slov i znacheniy russkogo yazyka [Explanatory Dictionary of Russian new words and meanings]. Moscow: AST: Astrel'.

5. Butseva, T.N. (ed.) (2009-2014) Novye slova i znacheniya. Slovar'-spravochnik po materialam pressy i literatury 90-kh godov XX veka: $V 2 t$. [New words and meanings. Dictionary of the materials of the press and literature of the 1990s: In 2 vols]. St. Petersburg: Dmitriy Bulanin.

6. Kotelova, N.Z. (ed.) (1995) Slovar' novykh slov russkogo yazyka (seredina 50-khseredina 80-kh godov) [Dictionary of new words of the Russian language (mid-50s - mid80s)]. St. Petersburg: Dmitriy Bulanin.

7. Sklyarevskaya, G.N. (ed.) (2008) Tolkovyy slovar' russkogo yazyka nachala XXI veka. Aktual'naya leksika: ok. 8500 slov i ustoychivykh slovosochetaniy [The Explanatory Dictionary of the Russian language of the early 21 st century. Current vocabulary: approx. 8500 words and phrases]. Moscow: Eksmo.

8. Sklyarevskaya, G.N. (ed.) (2001) Tolkovyy slovar' sovremennogo russkogo yazyka: Yazykovye izmeneniya kontsa XX stoletiya [The explanatory dictionary of modern Russian language: Language change in the end of the 20th century]. Moscow: Astrel': AST.

9. Bernshteyn, S.I. et al. (2000) Slovar' yazyka Pushkina: V 4 t. [Dictionary of Pushkin's Language: in 4 vols]. 2nd ed. Moscow: V. V. Vinogradov Russian Language Institute, RAS.

10. Karaulov, Yu.N. (ed.) (2001-2002) Slovar' yazyka Dostoevskogo: Leks. stroy idiolekta: $V 2-k h k n$. [Dictionary of Dostoevsky's language: Lexical system of the idiolect: In 2 books]. Moscow: Azbukovnik. 
11. Sudavichene, L.V. (ed.)(1998) Slovar' yazyka K.G. Paustovskogo: V 8 t. [Dictionary of K.G. Paustovsky's Language: in 8 vols]. Moscow: Izd-vo Mosk. lit. muzeya-tsentra K.G. Paustovskogo.

12. Bayramova, T.F. \& Nikishaeva, V.P. (2002) Slovar' yazyka rasskazov V.M. Shukshina: V 3-kh vyp. [Dictionary of Shukshin's Language: in 3 vols]. Biysk: Biysk State Pedagogical University.

13. Shipulina, G.I. (2013) Slovar' yazyka Esenina: glagol [Dictionary of Esenin's Language: verb]. Baku: Mutardzhim.

14. Dibrova, E.I. et al. (2014) Slovar' yazyka Mikhaila Sholokhova [Dictionary of Mikhail Sholokhov's Language]. Moscow: Slovari.ru.

15. Khusnutdinov, A.A. \& Khusnutdinova, A.A. (2012) Slovar' yazyka A.N. Ostrovskogo [Dictionary of A.N. Ostrovsky's Language]. In 4 vols. Shuya: Shuya State Pedagogical University.

16. Vasil'ev, N.L. \& Zhatkin, D.N. (2009) Slovar' yazyka A.A. Del'viga [Dictionary of A.A. Delvig's Language]. Moscow: Flinta: Nauka.

17. Vasil'ev, A.I. (2011) Frazeologicheskiy slovar' yazyka I.A. Bunina [Phraseological Dictionary of I.A. Bunin's Language]. Elets: Elets State University.

18. Polyakov, A.E. (2011) Slovar' yazyka A.S. Griboedova [Dictionary of A.S. Griboyedov's Language]. Vol. 1. Moscow: Yazyki slavyanskoy kul'tury.

19. Kazanskiy, N.N. (ed.) (2010) Slovar' yazyka M.V. Lomonosova [Dictionary of M.V. Lomonosov's Language]. In 2 vols. St. Petersburg: Nestor-Istoriya.

20. Filin, P.P. (ed.) (1974) Slovar' yazyka V.I. Lenina: Proekt [Dictionary of V.I. Lenin's Language: a project]. Moscow.

21. Samotik, L.G. (2004) Slovar' yazyka Aleksandra Lebedya [Dictionary of Alexander Lebed's Language]. Krasnoyarsk: Amal'gama.

22. Tolstova, G.A. (2004) Slovar' yazyka Agaf'i Lykovoy [Dictionary of Agafiya Lykova's Language]. Krasnoyarsk: Krasnoyarsk State Pedagogical University.

23. Vafin, B.D. \& Galiullin, K.R. (2012) Rossiya i Vostok: slovar' yazyka dokumentov po russko-indiyskim otnosheniyam XVII veka: konkordans, obratnyy slovoformoukazatel', chastotnyy slovoformoukazatel' [Russia and the East: Dictionary of the language of documents on Russian-Indian relations in the 17th century: concordance, reverse word form index, frequency word form index] Kazan: Kazan State University.

24. Elmor, R.T. (1992) Slovar' yazyka sredstv massovoy informatsii SShA [Dictionary of the language of the US media]. Moscow: Russkiy yazyk.

25. Sharipova, O.A. (2012) Slovar' yazyka goroda: (regional'nyy aspekt: g. Sterlitamak, Respublika Bashkortostan) [Dictionary of the language of the city (regional aspect: Sterlitamak, Bashkortostan Republic)]. Sterlitamak: Sterlitamak Branch of Bashkir State University.

26. Rogaleva, O.S. (2005) Brachnoe ob"yavlenie kak rechevoy zhanr reklamnogo diskursa (kommunikativno-pragmaticheskiy i kognitivnyy aspekty) [Marriage ad as a speech genre of advertising discourse (communicative- pragmatic and cognitive aspects)]. Abstract of Philology Cand. Diss. Omsk.

27. Bogdanova-Beglaryan, N.V. (2012) Construction (. . ) skazhem (let us say) (...) in Everyday Russian Speech (materials for dictionary of discursive units). Vestnik Kalmytskogo instituta gumanitarnykh issledovaniy RAN. 2. pp. 153-157.

28. Ivantsova, E.V. (2013) Lexicographical representation of an individual's speech: type of dictionary and its use in dictionary practice. Voprosy leksikografii - Russian Journal of Lexicography. 2 (4). pp. 5-18. (In Russian). 
29. Ubiyko, V.I. \& Battalova, A.R. (2012) The discursive and cognitive dictionary in communicative perspective. Kognitivnye issledovaniya yazyka. 11. pp. 546-548. (In Russian).

30. Chepasova, A.M. (1983) Semanticheskie i grammaticheskie svoystva frazeologizmov [The semantic and grammatical properties of idioms]. Chelyabinsk: Chelyabinsk State Pedagogical University.

31. Gvazava, V.I. (2001) [The epistolary heritage of the elite of the Russian nobility]. Russkiy yazyk: istoricheskie sud'by i sovremennost' [Russian language: historical destiny and modernity]. Proceedings of the International Congress of Russian Language Researchers. 13-16 March 2001. Moscow: Moscow State University. pp. 42. (In Russian).

32. Kasavin, I.T. (1998) Migratsiya. Kreativnost'. Tekst. Problemy neklassicheskoy teorii poznaniya [Migration. Creativity. Text. Problems of the non-classical theory of cognition]. St. Petersburg: RKhGI.

33. Kovaleva, N.A. (2002) Russkoe chastnoe pis'mo XIX veka. Kommunikatsiya. Zhanr. Rechevaya struktura [Russian private letter of the 19th century. Communication. Genre. Speech structure]. Abstract of Philology Dr. Diss. Moscow.

34. Gak, V.G. (1998) Asimmetriya [Asymmetry]. In: Yartseva, V.N. (ed.) Yazykoznanie. Bol'shoy entsiklopedicheskiy slovar' [Linguistics. The Big Encyclopaedic Dictionary]. Moscow: Bol'shaya Rossiyskaya Entsiklopediya.

35. Dronova, L.P. (2012) Issues of lexicography and anthropological linguistics. Voprosy leksikografii - Russian Journal of Lexicography. 2. pp. 26-32. (In Russian). 